Мушировська, Наталія. «Функціонування народнопоетичної символіки у поезії українського символізму (на матеріалі творчості В. Пачовського)». Лінгвостилістичні студії, вип. 10, 2019, с. 101-113.

Mushyrovska, Nataliia. "Functioning of the Folk Poetic Symbols in the Poetry of Ukrainian Symbolism (Case Study of V. Pachovskyi's creativity)". Linguostylistic Studies, iss. 10, 2019, pp. 101-113.

Удк 811.161.2' 38

https://doi.org/10.29038/2413-0923-2019-10-101-113

\title{
ФУНКЦІОНУВАННЯ НАРОДНОПОЕТИЧНОЇ СИМВОЛІКИ У ПОЕЗІЇ УКРАЇНСЬКОГО СИМВОЛІЗМУ (НА МАТЕРІАЛІ ТВОРЧОСТІ В. ПАЧОВСЬКОГО)
}

\author{
Наталія Мушировська \\ Рівненський державний гуманітарний університет, \\ Рівне, Україна
}

У статті на основі когнітивного підходу до аналізу стилістичних одиниць досліджено мовно-символічний код поезії українського символізму кінця XIX - початку $\mathrm{XX}$ ст. на прикладі поетичних текстів одного 3 яскравих його передставників В. Пачовського. На основі закономірностей функціонування символічної образності у його творах виявлено особливості когнітивного наповнення народнопоетичної символіки у художньому дискурсі поезії символізму зазначеного періоду, встановлено особливості індивідуально-авторського значеннєвого оновлення символів. Проаналізовано фреймово-слотову організацію народнопоетичних концептів i з'ясовано їх роль у вербалізації авторської мовної картини світу.

Ключові слова: ідіостиль, мовна картина світу, концептуальна картина світу, когнітивна стилістика, символ, народнопоетичний символ, концепт, фрейм, слот.

Mushyrovska Nataliia. Functioning of the Folk Poetic Symbols in the Poetry of Ukrainian Symbolism (Case Study of V. Pachovskyi's creativity). Thearticle describes an investigation of the linguistic and symbolic code of poetry of the Ukrainian symbolism of the late nineteenth and early twentieth centuries using the works of V. Pachovsky, who was one of the representatives of that poetic movement. The case study is based on the cognitive approach to the analysis of stylistic units. The cognitive meaning of the folk poetic symbols in the discourse of the poetry of symbolism of the specified period is considered on the basis of the regularity of the symbolic imagery functioning in the poet's writings. The study has revealed the specificity of the individual and authorial symbolic renewal of symbols. The frame-slot organization of folk poetic concepts, their role in verbalizing the author's linguistic picture of the world are in the focus of the analysis. The approach used by cognitive stylistics is based on the theories that explain the choice of the linguistic means through cognitive structures and processes underlying their formation The approach used by cognitive stylistics is based on theories that explain the choice of linguistic means through cognitive structures and processes underlying their formation. The main methods of cognition are used in this work, in particular the metaphorical analysis and the methods of transformation and distributive analysis. These methods enable modeling of the main folk poetic concepts in the works of V. Pachovskyi, a poet-symbolist. The research material comprises the poetic segments that contain the above mentioned ethnocultural concepts, as well as their frame organization. The emphasis is laid on the basic concepts related to the folk poetic symbols, for

(c) Мушировська Н., Східноєвропейський національний університет імені Лесі Українки, 2019.

Це стаття відкритого доступу на умовах СC BY-NC 4.0 
example, a concept of a bird (dove, swallowtail, cuckoo, cranes, peacock, hawk, raven, eagle, swan, nightingale), a concept of a snake, concepts of plants and flowers (rose, lily, cornflowers), etc.

The conducted research allows to draw a conclusion that the folk poetic symbols in the discourse of the symbolists of the late nineteenth and early twentieth century function not only as the means of intensification and deepening the imagery or expression of folklore details, but also as cognitive presentation of the individual author's picture of the world. The analyzed concepts convey the ethno-cultural information, since Ukrainian symbolism has grown on a national basis. Symbolists sought to combine common cultural heritage and national worldview. Therefore, in the process of verbalizing traditional concepts, $\mathrm{V}$. Pachovsky employed new senses which characterize the author's picture of the world. Decoding the conceptual content of folk poetic symbols enables and contribute to deeper understanding of the texts of the symbolism age.

Key words: idiostyle, linguistic picture of the world, conceptual picture of the world, cognitive stylistics, symbol, folk poetic symbol, concept, frame, slot.

Вступ. Вивчення ідіостилів як систем добору, осмислення i розташування мовних одиниць - важлива і перспективна проблема стилістики. Наприкінці XX ст. під впливом нових напрямків лінгвістики у стилістиці відбувається перегляд основних методів дослідження. Лінгвістична наука розширила свої горизонти і звернулася до вивчення когнітивних процесів породження і сприйняття тексту, що уможливлює нові шляхи дослідження традиційних проблем стилістики: якщо традиційні стилістичні прийоми розглядаються в структурному, семантичному і функціональному аспектах, то в руслі антропологічної парадигми проблема стилістичних прийомів постає 3 погляду їхньої когнітивної і лінгвокультурологічної специфіки.

Сьогодні зростає роль когнітивної стилістики, яка займає простір між лінгвістикою, літературознавством і когнітивістикою, поєднуючи лінгвістичний аналіз із досягненнями когнітивної психології для більш повного розуміння літературних і мовних явищ (Лунькова). Термінологічно, в якості самостійного наукового напряму у дослідженні художнього тексту, когнітивна стилістика утвердилася не так давно, зокрема, термін «когнітивна стилістика» почали вживати Дж. Калпепер і Е. Семіно (Лунькова). Підхід, що застосовується когнітивною стилістікою, базується на теоріях, які пояснюють вибір мовних засобів за допомогою когнітивних структур і процесів, що лежать в основі їх формування.

Когнітивна стилістика від традиційної функціональної стилістики відрізняється тим, що вона звертає увагу на ментальну, а не на текстову репрезентацію. Це вимагає знайти рівновагу у дослідженні когнітивнотекстового континууму. Концентрування тільки на текстовому підході викликає ризик втратити бачення того, що відбувається з читачем в процесі читання, i, таким чином, втратити творчу складову художнього тексту. 3 іншого боку, повністю сфокусувати увагу на когнітивному підході значить абстрагуватися від того, як організований текст, і це не дозволяє побачити всю стилізовану специфіку композиції тексту (Лунькова). 
В. Виноградов вказував на неможливість одностороннього - тільки літературного або тільки лінгвістичного - підходу до вивчення художніх текстів, оскільки в першому випадку залишається поза увагою мова як першоелемент, в іншому - дослідження обмежене тільки аналізом мови. Вчений вважав, що системний аналіз мови художньої літератури не повинен обмежуватися вузьким лінгвістичним підходом, закликаючи відійти від схематизму до живої мови літературного твору. За В. Виноградовим, стилістичний опис твору повинен передбачати розгляд системи індивідуально-творчого добору символів, встановлюючи їх типи й історичну послідовність, значення та шляхи розвитку (136).

Перспективи когнітивного підходу набувають для стилістики певного практичного значення: когнітивний підхід здатний об'єднати позицію автора і читача в дослідженні смислів тексту, інтегрувати концепцію кодування і декодування, зробити результат розшифрування вербальних знаків у іхній взаємодії і взаємовпливах багатовимірним і більш повним. Когнітивний метод в стилістиці дозволяє поєднати дві конкуруючі традиції у вивченні літературного твору - словоцентризм і антропоцентризм, зробити аналіз художнього тексту біполярним, де рівносильними і рівноправними центрами тяжіння стають слово і людина (Лунькова).

Актуальність дослідження народнопоетичних символів як структурно-семантичних явищ i вербалізованих засобів пізнання навколишнього світу, індивідуально-авторського бачення, втіленого у художньому творі, визначається тим, що вони маніфестують процеси, характерні для відповідного етапу розвитку художньої мови, характеризують особливості взаємодії колективного й індивідуального в культурі взагалі та їі окремих концептуалізованих виявах, зокрема, відбивають специфіку індивідуального світобачення та його реалізацію у художньому тексті.

Мета дослідження - проаналізувати мовно-символічний код поезії українського символізму кінця XIX - початку XX ст., грунтуючись на текстах одного з яскравих його передставників В. Пачовського. Через виявлення закономірностей функціонування символічної образності у його творах визначити особливості когнітивного наповнення народнопоетичної символіки у художньому дискурсі поезії символізму зазначеного періоду, дослідити індивідуально-авторську систему значеннєвого оновлення традиційних символів як засобів вираження змісту.

Матеріал і методи дослідження. Наукова увага до мовностилістичних одиниць народнопоетичного характеру засвідчена працями багатьох науковців. Лінгвістичне дослідження слів-символів сьогодні виходить за межі онтології, семіотики, культурології, літературознавства, фольклористики. Однак мовознавча наука потребує більш детального висвітлення проблеми народнопоетичного символу як стилістичної домінанти 
поетичної картини світу символізму кінця XIX - початку XX століття, який би був здійснений із погляду когнітивного підходу на прикладі ідіостилю його яскравих представників.

Дослідження проведене на матеріалі поетичних творів В. Пачовського різних років, вміщених, зокрема, у збірках «Розсипані перли», «На стоці гір», «Ладі й Марені - терновий огонь мій», «Огні мести». У роботі використані основні методи когнітології, зокрема, метафоричний аналіз (Дж. Лакофф i M. Джонсон), методика трансформаційного i дистрибутивного аналізу, що дають можливість моделювання основних народнопоетичних концептів у творах В. Пачовського як поета-символіста.

Результати дослідження та дискусія. Основною структурою в індивідуальному художньому тексті $\epsilon$ авторська модель світу. Індивідуальний стиль письменника висвітлюється через поняття «авторська свідомість», «світобачення письменника», «мовна картина світу». Індивідуальна художньо-мовна картина світу $\epsilon$ особливістю естетичного осягнення дійсності, iї феномен визначається, з одного боку, стильовою домінантою художнього тексту, а з іншого - вона виростає 3 національної мови та їі словника і формується під впливом традицій художнього мовлення, стильової концепції епохи. Вона знаходить вираження у символічному моделюванні дійсності.

Дослідники розмежовують мовну і концептуальну картину світу, хоча, як зазначає О. Селіванова, «...більш правильним було б говорити про мовомисленнєву картину світу, не ототожнюючи мову й мислення, а підводячи під мовну модель когнітивну базу» (407). В. Жайворонок вказує на те, що «...кожна мовна одиниця зорієнтована на концептуальний простір довкілля, стаючи мовленнєвим виявом того чи іншого його фрагмента» (Жайворонок, Проблема 11). Межа між концептуальною і мовною картинами світу нечітка через неможливість відокремлення процесів когніції від вербалізації. «Концептуальна та мовна картини світу розглядаються здебільшого на підставі логічних відношень перетину або включення другої до першої залежно від визнання концептуально не співвідносних мовних категорій...» (Селіванова 407).

Концепт - термін, що слугує поясненню одиниць ментальних чи психічних ресурсів нашої свідомості і тієї інформаційної структури, яка відображає знання і досвід людини; оперативна змістова одиниця пам'яті, ментального лексикону, концептуальної системи і мови мозку (linguamentalis), усієї картини світу, що відображається у людській психіці. (Кубрякова, Демьянков, Панкрац, и Лузина 89-90). За О.Селівановою, «концепти - інформаційні структури свідомості, різносубстратні за способами формування та представлення знань про певні об'єкти та явища. Концептуалізація поряд із категоризацією є ключовим поняттям когнітивної лінгвістики, адже фіксація певного концепту за мовним знаком $\epsilon$ базою формування семантичного простору мови. Збереження та 
трансляція концептосистеми відбувається переважно за рахунок вербалізації концептів (406).

Н. Болдирєв зазначає, що, передаючи той чи інший концепт, лексична одиниця активує і відповідний когнітивний контекст або фрейм як модель побутового знання про основні концепти. М. Мінський визначав фрейм як структуру інформаційних даних, у якій відображено набуті досвідним шляхом знання про деяку стереотипну ситуацію та про текст, що її описує (Кубрякова, Демьянков, Панкрац, и Лузина 397).

Фрейм розглядають як структуру, у якій паралельно використовуються вербальні і невербальні типи інформації з огляду на те, що невербальні форми завжди можуть бути організовані через вербальні (Селіванова 398). «Формально структуру фрейму представляють як дворівневу або польову. Згідно з концепцією М. Мінського, фрейм $є$ сіткою вузлів і зв'язків між ними. Верхні рівні фрейму чітко визначені, оскільки утворені такими поняттями, що є завжди справедливими відносно ситуації. На нижніх рівнях наявні чарунки, або термінальні вузли чи слоти, які заповнюються конкретними даними у процесі приведення фрейму у відповідність до певної ситуації» (Селіванова 398).

У роботі спираємося на визначення понять О. Селіванової: «концепт згусток культури у свідомості людини; те, у вигляді чого культура входить у ментальний світ людини»; «культурний концепт - багатовимірна смислова величина, що містить у собі ціннісний, образний і поняттєвий складники»; «фрейм - структура репрезентації знань, в якій відображено набуту досвідним шляхом інформацію про деяку ситуацію та про текст, що їі описує, а також інструкцію щодо її використання»; «слоти - елементи ситуацій, певного типу інформації, релевантної для фрагмента описуваної дійсності».

Символ, за В. Виноградовим, є семантичною організацією поетичної мови. Він сприймається і осягається на фоні звичних лексем. Загальною рисою символу, за твердженням науковців, $\epsilon$ інакомовність, здатність позначати щось окрім свого основного значення (Лосев). Таким розумінням символу керувались у своїй художньо-словесній творчості поети-символісти.

Народнопоетичні символи у поетичних текстах кінця XIX - початку XX століття - це не просто слова-знаки, вони передусім виступають «концептуальними» репрезентантами авторської картини світу із властивими аксіологічними параметрами етнокультури (Ю.Степанов). Ключовими в художньому дискурсі окресленого періоду, який репрезентує поезія В. Пачовського, були традиційні народні символи флори (квіти, трави, дерева) і фауни (птахи, плазуни), тісно пов'язані з народними звичаями, піснями, переказами, традиціями. Символіка ранніх символістів зосереджена на певному колі улюблених символів, їх уживання має ознаки загальної тенденції. Особливо виразними є народнопоетичні символи пташка, зозуля, галка, журавлиний ключ, соловей, крук, ворон, пугач, 
ластівка, лебідь, орел, чайка (мева), голуб; змія, вуж; квітка, вінок, лелія, рожа, фіалка, барвінок, незабудки, васильки, чорнобривці, полин, рута, шавлія, лоза, тройзілля, мак, вишня, калина, папороть; ліщина (горіх), черешні, калина, малина, тополя. Головна ознака таких ключових символів повторюваність і частотність виступання у творчості автора і поетів омовленої епохи. Виокремлення таких ключових символів не залежить від того, чим $\epsilon$ образ з погляду поетики - метафорою, порівнянням, традиційним, універсальним чи індивідуальним символом. Застосування подібних символів може бути як цілком усвідомленим, так і не зовсім, вони вказують на життєвість якоїсь проблематики, на індивідуальну чи збірну тенденцію, віру, програму. Такий символ наближується до поняття міфу, може мати архетипний характер.

Слід розглянути поетичні сегменти, що містять наведені етнокультурні концепти, а також їхню фреймову організацію та слоти.

Одним із найбільш поширених образів-символів означеного періоду був nmax, концептуальне значення якого у В. Пачовського представлене фреймом душа, що була одним із лейтмотивів літератури доби модернізму. Тлумачення птаха як символу душі $\epsilon$ поширеним у народній творчості (В. Пропп, Дж. Фрезер). Слотами виступають співала, слово, жива: «Не вірить ніжній моїй мові, / Хоч слухала тихі слова - / Співала їх слово по слові / Душа моя, пташка жива» (Пачовський 261).

У психологічній інтерпретації К. Юнга птахи уособлюють духів чи ангелів, підтримку вищих сил, думку і політ фантазії (Юнг 422). Ця семантика поширюється на символіку лету, крил, пір'їн тощо. Концепт пташка співвідноситься з фреймом кохання, де слотами є крила, пір'я, незлагода, сльози, коштовності, квіти: «Так як пташки крильми бились, / То не піря розронились, / А хрусталі краскомінні, / Гіркі сльози поломінні, / Чорнобривцями!» (Пачовський 36). Створюючи естетизований, театралізований образ кохання, В. Пачовський, поєднує символи, що $є$ особливістю ідіостилю поета з притаманними йому легкістю, грайливістю та багатством образно-символічної палітри.

Концепт голуб зіставний із фреймом кохання. Для народної поезії голуби - символ найвірнішої любові. 3 цим значенням образ вживається у В. Пачовського. Слотами є весна, цвіт, життя, світ: «Пара голубів гуркоче / Наче слухати не хоче / Соловейкових пісень / Ой гуркоче, буркотає, / Одно друге обіймає - / Обсипає з гілля цвіт. / I цілується з собою / Сад жемчужиться росою - / Усміхається весь світ!..» (Пачовський 74).

Поширеним символічним образом у поезії доби символізму, пов'язаним з символізмом пір року (Б. Лепкий, В. Пачовський та інші), $\epsilon$ журавлиний ключ. Наповнення концепту журавлиний ключ співвідносне 3 фреймом сум, що приховано відчувається у віталістичній радості весни і життя, та слотами втрачена молодість, вирій, жаль, сльози, за якими вгадується потойбіччя: «I кого весна цілує, / Личко рожами малює, / Тому блиснуть перли з уст; / А кому весна минула, / 3 журавлями не вернула, / 
Тому ринуть сльози з віч» (Пачовський 32). Концепт журавлиний ключ також репрезентований фреймом пошуків забуття, пориву «далі від усього світу», де слотами є вирій, забуття, чужина: «Ключем надлинуть журавлі, / Летіти му на їх чолі, / Співаючи свій спів! / Полину з ними у вирій, / Найду гей забуття сновій / В далекій стороні» (Пачовський 125).

Концепт ластівка співвідносний з фреймом весна. Традиція зустрічі весни, притаманна українцям, пов'язана з прильотом перших весняних птахів, що відкривають нове життя. Він підтримується слотами сонще, радість, кохання: «Весна зеленіє / Бо сонце вже гріє - / Вернувся вірей, / Вже ластівка шлеться, / Все скаче, сміється, / Всім личко сия / Лиш я не сміюся - / Далеко Гануся, / Далеко моя!» (Пачовський 59). Образ ластівки має загальнокультурне символічне навантаження, адже вона присвячена Ізиді й Венері, є втіленням весни і любові.

Концепт зозуля співвіднесений із фреймом смуток, як і у фольклорі, i виражений слотами минуле щастя, мовчання зозулі, втрачена весна: «Гей закуй мені, зозуле, / Щастя, на весні минуле, / Заверни мені! / А зозуля мов не чує / Сіла, пала тай не чує, / Як кувала навесні» (Пачовський 128).

Символіка птаха часто використовується В. Пачовським для змалювання жіночих образів, поет залучає такі символи, як галка, орлиця, лебідка, мева, залежно від того, що хоче підкреслити в образі коханої - духовність, чуттєвість, красу або погорду. У них поєднується фольклорний символізм з багатозначністю настроєвого символу.

Одним із найулюбленіших символів сецесії був павич. Концепт пава у ліриці В. Пачовського співвідносний $з$ фреймом жінка, дівчина і реалізується у слотах царськість, краса, амбівалентність, наповнюється символікою кольорів: чорна пава, біла пава: «Сіла, пала пава біла, / Що любить мій спів - / Мою душу упоїла, / Як фіялка, як русалка, / Чаром любих слів» (Пачовський 482).

Архетипний зміст символа, як і настроєвий, пов'язаний із птахом, часто стає втіленням у ліриці В. Пачовського темної, лиховісної сторони буття. Зокрема, концепт шуліки співвідносний із фреймами недобрих сил, страждання та слотами чорні звістки, думки, муки, кров: «Шлються чорні вісті з кинутого краю, / Як шуліки грають мені в голові - / Шарпають за серце, мовчу і втікаю, / Куди не заходять земляки живі - / Там скажені звіри, вражі бузувіри / Мучать і катують мій народ в крові!» (Пачовський 362).

Чимало творів В. Пачовського, схильного до світлих, гедоністичних переживань, мають ознаки декадансу - відчуття містичного жаху, пов'язаного зі смертю. Концепт крук співвідносний із фреймом смерть та слотами фінал, коса, болото, провал, туга: "Десь кракне крук, та між хрестами / Вже відьма грає фінал, / Коса бренчить між кістяками, / A я застряг між болотами, / І суну ся в провал! / А туга виє: гу-гу! / Прийдеш ти на чергу!» (Пачовський 190).

У культурній традиції птахи здатні виступати деміургами, перевтіленнями героїв, тотемними істотами, міфологічними класифікаторами 
і символами божественної сутності, неба, духу і душі, свободи, натхнення, пророцтва, зв'язку між космічними законами душі, духу і життя. Ці ознаки в поезії В. Пачовського має образ орла. Зазвичай народна свідомість у цьому птахові вбачає символ мужності, боротьби, відповідник чоловіка, коханого, доблесті, молодечої слави, побратима козака (Костомаров, «Несколько слов» 99), що узяв до уваги В. Пачовський, творчо переосмисливши народну творчість. У нього концепт орел, співвідносний 3 фреймом гордість, представлений слотами дух, крила, має риси автопоетичності : «Бо дух мій гордий як орел, / Що має кігті й крила» (Пачовський 467). Концепт орлині крила співвідносний з фреймами думка, сила духу, трансценденція. Вони містять слоти рідний край, пекло, чистилище, огонь, небо у візійних картинах історичного минулого i майбутнього народу: «Як в край рідний вернем мила, / Стрілять з пліч орлині крила / А світла святі з долонь - / 3 пекла перейдем до неба / Крізь чистилище, де треба / Йти через огонь!» (Пачовський 446).

Одним із найвідоміших символів епохи символізму був лебідь, який приваблював митців мальовничістю та прихованими сенсами. Його зовнішні якості до конструювання метафоричного чи синестезійного образу-символу практично не були залучені, використовувались переважно традиційні народнопоетичні та культурологічні значення. У народній поезії образ лебедя часто символізує жінку, дівчину (лебідонька, лебідка) (Костомаров, «Об историческом» 102). У В. Пачовського концепт лебідь, співвідносний із фреймом наречена, представлений слотами: сватання, втрата пари: «За лебідку круки б'ються / Наступає чорна хмара - / Круки на заваллю, / До Ольдзюні люди шлються, / Ми не будем собі пара - / Я загину з жалю!» (Пачовський 123). Концепт лебідь також співвідносний 3 фреймом дівчина, слоти - чари, краса: «Аж се діва счарувала / Його чаром лебедінь!» (Пачовський 221). Культурні значення символіки білого лебедя, пов'язані з Венерою, цнотливою наготою і незаплямованою білизною (Керлот 285). Такі значення символіки лебедя дали поштовх для розгортання цього народнопоетичного символу у сенсі модерністської еротики. Концепт лебідь співвідноситься з фреймом дівчина, слоти оголеність, краса, гріх, сміх: «Простягнена на грудях у мене, / Як лебідь біленька і яра / Смієш ся як пяна з гріху...» (Пачовський 277). У ранніх збірках В. Пачовського образ лебедя $\epsilon$ типово народнопоетичним, знаковим, вмонтованим у стилізовану народнопісенну лірику. Концепт лебідь співвідноситься також з фреймом хлопещь, слоти - самотність, втрата коханої: «Летів лебідь попід хмари, / А не мав той лебідь пари, / Не мав пари, тілько жаль - / Жаль на тих, що пару взяли, / 3 пари його розігнали - / Линув сам світами в даль» (Пачовський 88).

Автопоетичним символом стає у В. Пачовського образ солов'я, що $\epsilon$ органічним в українській традиції як означник народного співця і барда (Костомаров, «Об историческом» 95-96). Він наповнений полемікою про завдання поета, його громадянські дії та патріотичні вчинки в ім'я свого 
народу. Концепт соловей співвідносний із фреймом поет та зі слотами ненька (батьківщина), праця, струни душі: «Пісні від мене прийми, моя Нене, / В твоїм садочку я твій соловій! / Воли орють землю, луна йде до мене, / Так струни всі грають в душі молодій» (Пачовський 159).

Пташці як істоті вищих духовних сфер протистоять плазуни, змії, ящірки, пиявки, в'юни, саламандри, що були надзвичайно поширені у мистецтві сецесії та натякали на символіку нижнього світу - глибин, печер, боліт. У народній традиції плазуну приписують значення зла, гріха. Концепти змія, вуж, гадюка, в'юн, п'явка репрезентують у поезії В. Пачовського фрейм жіноча природа та слоти в'юнкість, гнучкість, тіло, ніч: «Тягнуть брови в'юнкістю піявки, / Тягне гнучкість тіла гей у мавки...» (Пачовський 107); «Як в'юн руками обведе / I n'є устами очі, / Огонь з душі мені краде / Страшна царівна ночі» (Пачовський 276), а також смерть, безодня зі слотами страх, хрест: «На хрест десь мене заповзято, / А ти нахилилась до уст, / Страшна як медуза волоссям, / Гадюками вкрила мій бюст» (Пачовський 213). Поет прагне збагнути «двоїстість» жінки, яка за своєю суттю протилежна «цілісному» чоловікові, позбавляє його «крил».

Поезію В. Пачовського наповнюють фольклорні символи рослин та квітів: явір, дуб, калина, тополя, верба, лоза, малини, вишні, рута, шавлія, чорнобривці, дзвіночки, полин. Змістове наповнення цих символів традиційне: завданням цієї символіки $є$ створити народнопоетичний колорит. До прикладу, концепти рута, шалвія співвідносні з фреймами смуток, розлука, дівування, самотність, туга та слотами яра, отрута, по мені: «Посходила яра рута, / Яра рута та отрута / I шалвія по весні, / По садочку Гандзя ходить, / Тай когось за руку водить, / Когось водить по мені» (Пачовський 84). Концептуальне значення символу барвінок відповідає народнопоетичному і співставне з фреймами вічність, життя, сила, слотами тут є шлюб, вінок, ярий: «Візьме хтось тебе за жінку / В ярім вінку із барвінку, / Що ж останеться мені?» (Пачовський 43).

У поезії В. Пачовського зустрічаємось $з$ традицією як фольклорною, так і загальнокультурною, асоціювати жіночу вроду з символами - рожею, лелією, фіалкою. Більшість з них мають закріплені словникові значення, що здатні трансформуватись у настроєві та міфологічні. Концепт квітка співвідносний із фреймом дівчина, жінка та слотами рожа, лелія, фіалка, мрія, русалка: «Червона рожа, біла лелія, / Та запашніша фіалка - / Над всі чужинки краща як мрія, / 3 рідного краю русалка!» (Пачовський 462).

Улюблені символи у В.Пачовського - троянда (рожа) та лілея. Символічне значення троянди полягає в тому, що вона втілює завершеність, повноту i досконалість, кохання (Керлот 440). У В. Пачовського троянда здебільшого позбавлена містичних рис, на перший план виступає алегоризація кохання та еросу. Концепт троянда співвідносний із фреймом жіноча врода, слотами є Бог, тіло, казка, пісня: «Сам Бог взяв із рож і леліїв / Пах мірги і одур і краску - / Зрізьбив твоє тіло, мов казку / 3 пісень соловіїв / 3 пісень соловіїв, / 3 пісень!» 
(Пачовський 320). Серед найпоширеніших чуттєвих образів - «трояндиуста», що часто виступає в поєднанні з лілеями - білосніжним обличчям або персами красуні. Концепт рожа тут співвідносний 3 фреймом тілесність, слотами $є$ цілунок, обійми, трунок, хвилина: «Раз бути щасливим в цілунку, / В обіймах троянд і лелій - / Я плачу як Фавст з того трунку: / О, хвиле прекрасная, стій!» (Пачовський 426).

y поетичній системі В. Пачовського лілея, як i троянда амбівалентний символ, близький до алегорії, пов'язаний як зі святістю, так і 3 еротичністю. Біла лілея асоціюється у фольклорній і культурній традиції з тендітністю, чистотою і невинністю. У християнській традиції вона $\epsilon$ атрибутом святості, пов'язується 3 невинністю Діви Марії в символіці Благовіщення (Керлот 292). Концепт лілея у поезії В. Пачовського співвідносний з фреймами чистота, непорочність, зовнішня і внутрішня жіноча краса, слоти - кохана, мрія, чиста, невинна, наприклад: «Ой не любка то, а мрія - / Така чиста, як лелія, / Називається Марія...» (Пачовський 49); «Ти невинна ще така, / Як лелієчка яка, / Як лелієчка!» (Пачовський 78). Еротичний зміст, подібний біблійній «Пісні пісень», вкладає В. Пачовський у деякі свої алегорії, де концепт лелія представлений фреймом тілесність та слотами грудь, сяєво, сміх, гріх, мрії, заколисувати: «Очі, шию, волос твій, / Грудь сповиту з двох лелій, / Буду пить до щаду / Сонне сяєво сміху - / Поки в згарищах гріху / Без сил не упаду» (Пачовський 272); «Яка чудова - їі грудь - / Як дві лелії дишуть - / Весною пахощі несуть / I в мріях заколишуть!» (Пачовський 495).

Звертаючись до національних, українських народнопоетичних джерел, В. Пачовський порівнює кохання з казковими квітами. Так, серед поетичних символів поета - міфічні сон-трава, чар-зілля, тройзілля. Солярна символіка, притаманна слов'янській міфологічній традиції, виявляє себе у концепті «вогняних квітів», що мають стосунок до виквітів людської душі - почуттів, думок, мрій і бажань. Так, концепт чароцвіт співвідносний із фреймом душа, його представляють слоти сміх, іскри, зорі, провалля: «Той срібний сміх із уст твоїх / Упав як іскри з ясних зір - / Душа моя тепер сия, / Як чароцвіт в проваллі гір!» (Пачовський 251).

Особливе місце в ідіостилі символістів посідає образ синьої квітки, здатний асоціюватися 3 містичною таємницею, загадкою буття, якою овіяне кохання у символістів. У В. Пачовського широко представлений синій колір квітки у загальновідомих народнопоетичних образах-символах незабудки, фіалки, барвінку, васильків. Концепт незабудка розкривається у фреймі вічність спогадів та репрезентується слотами перли, синій цвіт: «Де розсипались ті перли, / Незабудьки поросли, / Незабудьки посходили, / Синім цвітом зацвіли / Та всі стежки, всі доріжки / Коло Дзюні поросли» (Пачовський 31). Концепт васильки, співвідносний у В. Пачовського, як і в народній поезії, із фреймом хлопия, коханого, стає автопоетичним, виявляється у слотах співати, Василь: «Не співай мені що хвильки / Про Василя і васильки / I принади не давай!» (Пачовський 511). 
Висновки i перспективи дослідження. Отже, проведене дослідження дає підстави стверджувати, що народнопоетичні символи у художньому дискурсі символістів кінця XIX - початку XX століття виступають не лише засобом інтенсифікації і поглиблення образності, експресивноті чи вираженням народнопісенного колориту, але й когнітивними репрезентантами індивідуально-авторської картини світу. Проаналізовані концепти є носіями етнокультурної інформації, оскільки український символізм виростав на національному грунті. Символісти прагнули поєднати загальнокультурні надбання та національне світобачення, тому у процесі вербалізації традиційних концептів В. Пачовським залучаються нові сенси, які характеризують індивідуальноавторську картину світу. Розшифрування концептуального змісту народнопоетичних символів стає шляхом до поглибинного розуміння текстів доби символізму.

\section{Список використаних джерел}

Пачовський, Василь. Зібрані твори. В 2 т. Філадельфія-Ню-Йорк-Торонто : Об'єднання українських письменників «Слово», 1984.

\section{Sources}

Pachovskyi, Vasyl. Zibrani tvory. 2 vols. Filadelfiia-Niu-York-Toronto: Obiednannia ukrainskykh pysmennykiv "Slovo", 1984.

\section{Список використаної літератури}

Болдырев, Николай. «Концепт и значение слова». Методологические проблемы когнитивной лингвистики, под ред. И. А. Стернина. Воронеж: ВГУ, 2001, с. 25-36.

Булашев, Георгій. Український народ у своїх легендах, релігійних поглядах та віруваннях. Київ : Фірма «Довіра», 1992.

Вежбицкая, Анна. Язык. Культура. Познание. Москва : Русские словари, 1997.

Виноградов, Виктор. Стилистика. Теория поэтической речи. Поэтика. Москва, 1963.

Войтович, Валерій. Сокіл-Род: легенди та міфи стародавніх українців. Рівне, 1997.

Воропай, Олекса. Звичаї нашого народу: етнографічний нарис. Київ : Оберіг, 1991.

Гнатюк, Володимир. Нарис української міфології. Львів, 2000.

Єрмоленко, Світлана. Фольклор і літературна мова. Київ : Наукова думка, 1987.

Жаботинская, Светлана. «Концептуальный анализ: типы фреймов». Вестник Черкасского университета, вып. 11, 1999, с. 3-20.

Жайворонок, Віталій. Знаки української етнокультури. Київ : Довіра, 2006.

Жайворонок, Віталій. «Проблема концептуальної картини світу та мовного їі відображення». Культура народов Причерноморья, № 32, 2002, с. 51-3.

Керлот, Хуан. Словарь символов. Москва : REFL-book, 1994.

Кононенко, Віталій. Концепти українського дискурсу. Київ-Івано-Франківськ : Плай, 2004.

Кононенко, Віталій. Мова у контексті культури. Київ - Івано-Франківськ, 2008.

Костомаров, Микола. «Несколько слов о славяно-русской мифологии в языческом периоде, преимущественно в связи с народною поэзиею». Слов'янська міфологія: вибрані праці з фольклористики й літературознавства. Київ : Либідь, 1994, с. 257-79. 
Костомаров, Микола. «Об историческом значении русской народной поэзии». Слов'янська міфологія: вибрані праці з фольклористики й літературознавства. Київ : Либідь, 1994, с. 44-201.

Костомаров, Микола. «Славянская міфологія». Слов'янська міфологія: вибрані праці 3 фольклористики й літературознавства. Київ : Либідь, 1994, с. 201-57.

Кубрякова, Е. С., Демьянков, В. З., Панкрац, Ю. Г., и Лузина, Л. Г. Краткий словарь когнитивных терминов. Москва, 1997.

Левченко, Олена. Дослідження вербальних символів у лінгвокультурологічному аспекті. URL: http://dspace.nbuv.gov.ua/ bitstream/handle/ 123456789/73947/07Levchenko.pdf? sequence $=1$

Левченко, Олена. Фразеологічна символіка: лінгвокультурологічний аспект. Львів, 2005.

Лосев, Алексей. Знак. Символ. Миф. Москва : Издательство МГУ, 1982.

Лосев, Алексей. Проблема символа и реалистическое искусство. Москва: Искусство, 1976.

Лунькова, Лариса. Когнитивная стилистика: обработка и декодирование художественного текста. Москва : РУСАЙНС, 2018.

Маслова, Валентина. Лингвокультурология. Москва : Издательский центр «Академия», 2001.

Потебня, Александр. «0 некоторых символах в славянской народной поэзии». Символ и миф в народной культуре. Москва : Лабиринт, 2000, с. 5-91.

Ріжко, Руслана. «Когнітивне наповнення фольклоризмів у поетичній картині світу кінця XX - початку XXI століття». Вісник Житомирського державного університету ім. Івана Франка: Філологічні науки, вип. 58, 2011, с. 186-192.

Селіванова, Олена. Сучасна лінгвістика: напрями та проблеми. Полтава: Довкілля-К, 2008.

Сімович, Оксана. Поетична символіка української народної творчості: лінгвістичний аспект. Львів, 1999.

Сліпушко, Оксана. Давньоукраїнський бестіарій: генезис і система. Київ: Дніпро, 2001.

Юнг, Карл. Человек и его символы. Москва : Серебрянные нити, 1997.

\section{References}

Boldyrev, Nikolaj. "Koncept i znachenie slova”. Metodologicheskie problemy kognitivnoj lingvistiki, edited by I. A. Sternin. Voronezh: VGU, 2001, pp. 25-36.

Bulashev, Heorhii. Ukrainskyi narod u svoikh lehendakh, relihiinykh pohliadakh ta viruvanniakh. Kyiv : Firma "Dovira", 1992.

Vezhbickaja, Anna. Jazyk. Kul'tura. Poznanie. Moskva : Russkie slovari, 1997.

Vinogradov, Viktor. Stilistika. Teorija pojeticheskoj rechi. Pojetika. Moskva, 1963.

Voitovych, Valerii. Sokil-Rod: lehendy ta mify starodavnikh ukraintsiv. Rivne, 1997.

Voropai, Oleksa. Zvychai nashoho narodu: etnohrafichnyi narys. Kyiv : Oberih, 1991.

Hnatiuk, Volodymyr. Narys ukrainskoi mifolohii. Lviv, 2000.

Yermolenko, Svitlana. Folklor i literaturna mova. Kyiv : Naukova dumka, 1987.

Zhabotinskaja, Svetlana. "Konceptual'nyj analiz: tipy frejmov". Cherkasy University Bulletin: Philological Sciences, iss. 11, 1999, pp. 3-20

Zhaivoronok, Vitalii. Znaky ukrainskoi etnokultury. Kyiv : Dovira, 2006.

Zhaivoronok, Vitalii. "Problema kontseptualnoi kartyny svitu ta movnoho yii vidobrazhennia". Kul'tura narodov Prichernomor'ja, no 32, 2002, pp. 51-3.

Kerlot, Huan. Slovar' simvolov. Moskva : REFL-book, 1994.

Kononenko, Vitalii. Kontsepty ukrainskoho dyskursu. Kyiv-Ivano-Frankivsk : Plai, 2004.

Kononenko, Vitalii. Mova u konteksti kultury. Kyiv - Ivano-Frankivsk, 2008. 
Kostomarov, Mykola. "Neskol'ko slov o slavjano-russkoj mifologii v jazycheskom periode, preimushhestvenno v svjazi s narodnoju pojezieju". Slovianska mifolohiia: vybrani pratsi z folklorystyky y literaturoznavstva. Kyiv : Lybid, 1994, pp. 257-79.

Kostomarov, Mykola. "Ob istoricheskom znachenii russkoj narodnoj pojezii". Slovianska mifolohiia: vybrani pratsi z folklorystyky y literaturoznavstva. Kyiv : Lybid, 1994, pp. 44-201.

Kostomarov, Mykola. "Slavianskaia mifolohiia". Slovianska mifolohiia: vybrani pratsi $z$ folklorystyky y literaturoznavstva. Kyiv : Lybid, 1994, pp. 201-57.

Kubrjakova, E. S., Dem'jankov, V. Z., Pankrac, Ju. G., and Luzina, L. G. Kratkij slovar' kognitivnyh terminov. Moskva, 1997.

Levchenko, Olena. Doslidzhennia verbalnykh symvoliv u linhvokulturolohichnomu aspekti. dspace.nbuv.gov.ua/ bitstream/handle/ 123456789/73947/07-Levchenko.pdf? sequence $=1$

Levchenko, Olena. Frazeolohichna symvolika: linhvokulturolohichnyi aspekt. Lviv, 2005.

Losev, Aleksej. Znak. Simvol. Mif. Moskva : Izdatel'stvo MGU, 1982.

Losev, Aleksej. Problema simvola i realisticheskoe iskusstvo. Moskva : Iskusstvo, 1976.

Lun'kova, Larisa. Kognitivnaja stilistika: obrabotka i dekodirovanie hudozhestvennogo teksta. Moskva : RUSAJNS, 2018.

Maslova, Valentina. Lingvokul'turologija. Moskva : Izdatel'skij centr “Akademija”, 2001.

Potebnja, Aleksandr. "O nekotoryh simvolah v slavjanskoj narodnoj pojezii". Simvol $i$ mif $v$ narodnoj kul'ture. Moskva : Labirint, 2000, pp. 5-91.

Rizhko, Ruslana. "The Folklorisms Cognitive Filling in the Poetic Picture of the World at the End of the XX - the beginning of the XXI Centuries". Zhytomyr Ivan Franko State University Journal, iss. 58, 2011, pp. 186-192.

Selivanova, Olena. Suchasna linhvistyka: napriamy ta problemy. Poltava: Dovkillia-K, 2008.

Simovych, Oksana. Poetychna symvolika ukrainskoi narodnoi tvorchosti: linhvistychnyi aspekt. Lviv, 1999.

Slipushko, Oksana. Davnoukrainskyi bestiarii: henezys i systema. Kyiv: Dnipro, 2001.

Jung, Carl. Chelovek i ego simvoly. Moskva : Serebrjannye niti, 1997.

Стаття надійшла до редколегії 19.02.2019 